\title{
Measurement of 'free' gold in patients receiving disodium aurothiomalate and the association of high free to total gold levels with toxicity
}

\author{
M J HEATH \\ From the Department of Clinical Chemistry, City Hospital, Nottingham
}

SUMMARY Serum from patients with rheumatoid arthritis (RA) receiving disodium aurothiomalate was analysed for total gold by atomic absorption spectrometry and for unbound (free) golit by the same method after ultrafiltration by an inert membrane. It was shown that it is possible to obtain reliable free gold concentrations by this method. Good correlations were shown between total and 'free' gold and between total and protein bound gold (PBG) for 54 patients with RA who were stabilised on gold therapy. Significant correlation was also shown between the same parameters for a second group of 15 patients starting gold therapy who were bled at week intervals for nine weeks immediately before medication. A single correlation with regression fof all patients studied again showed good correlation between total and free gold and between tot:\$S and PBG. Of the 189 paired values plotted, 182 fell within 2SD of the regression lines for the twe plots. Of the seven patients with results outside $2 \mathrm{SD}$ of the regression line, six presented with side effects during the study.

Key words: rheumatoid arthritis, unbound gold, gold therapy, chrysotherapy, gold measure $\frac{2}{2}$ ment.

It has been shown that most of the gold given to patients suffering from rheumatoid arthritis (RA) as aurothiomalate is present in the serum bound to albumin and to a lesser extent bound to the remaining protein fractions. ${ }^{1-8}$ It has also been established that with several drugs the unbound rather than the total or protein bound concentration shows a better correlation with pharmacological response. ${ }^{9-11}$ In consequence it has been suggested that unbound (or free) serum gold might be a useful parameter for monitoring patients during chrysotherapy. ${ }^{7} 12$

Until recently methods of assaying free serum gold have either been unsuccessful or have given inconsistent results, probably as a result of technical problems encountered at the very low levels of free gold. Many methods have not been suited to handling large numbers of specimens and have not been sufficiently fast to cope with the reactive characteristics of gold in blood or with the changing

Accepted for publication 3 Junc 1987.

Correspondence to $\mathrm{Mr} \mathrm{M} \mathrm{J}$ Heath, Department of Clinical Chemistry. City Hospital, Hucknall Road, Nottingham NG5 1PB. nature of plasma proteins with time. ${ }^{2}$ Furthermore, the redistribution of gold among the protein fract tions during separation and the reaction of metalle ions with chemicals have made the assay difficul?

Membrane ultrafiltration has been used success fully in studies where speed of analysis, withou addition of potentially competitive buffer components and electrolytes, has been required. ${ }^{13}$ This method has been used in studies of protein bindin to drugs, ${ }^{14} 15$ analysis of free tryptophan plasma, ${ }^{16}$ and the protein binding of sef hormones. ${ }^{17}$ Ultrafiltration has been shown to be at least equivalent to equilibrium dialysis but simplete to carry out. ${ }^{18}$ The aims of this study were to explofe the possibility of producing an ultrafiltrate of serux containing unbound gold using filtration membranes and to investigate the possible relations betwee total, free, and protein bound gold (PBG) in the serum of patients with RA receiving gold therapt

Patients and methods

PATIENTS

Two groups of patients were studied. 


\section{Group 1}

Fifty four patients who fulfilled the American Rheumatism Association (ARA) criteria for RA ${ }^{19}$ and who were stabilised on gold therapy (disodium aurothiomalate) had $10 \mathrm{ml}$ of blood withrawn by venous section before the next maintenance gold injection. Serum was separated from the clotted blood and stored at $4^{\circ} \mathrm{C}$ within 30 minutes of blood collection.

\section{Group 2}

A further 15 patients with RA who were starting gold therapy had blood withdrawn weekly for nine weeks before the next gold injection. The serum was stored at $4^{\circ} \mathrm{C}$ within 30 minutes of venous section as for group 1.

\section{SPECIMEN ANALYSIS}

All serum specimens were analysed for total gold and free gold. From these two values the PBG levels were calculated.

Total gold

Total gold levels were assayed by flame atomic absorption spectrometry. ${ }^{20}$

\section{Free gold}

Ultrafiltrates of serum were obtained using Amicon Centriflo membrane cones (type CF25), which are an inert, non-cellulosic polymer laminated on a tough inert substrate.

All specimens were centrifuged in an individual membrane cone at $4^{\circ} \mathrm{C}$ at a relative centrifugal force not exceeding $100 \mathrm{~g}$. (Excessive relative centrifugal force causes protein leakage.) The resulting ultrafiltrates were tested for pervading proteins using test strips (Boehringer BH). From a total of 189 serum specimens centrifuged, 10 filtrates were discarded after the detection of protein. In these cases there was sufficient serum left to repeat the filtration in new cones.

The protein free ultrafiltrates were analysed for gold by flame atomic absorption spectrometry.

Serum samples from 20 patients were filtered and analysed in duplicate as a test of the method precision (precision study). Each set of duplicate specimens assayed had gold values which were within $10 \%$ of each other.

STATISTICAL ANALYSIS OF RESULTS

Results from group 1 patients were analysed by Pearson correlation with linear regression. Correlation coefficients ( $r$ ) were calculated for total gold against free gold and total gold against protein bound gold.

Results obtained for group 2 patients were analysed by the same technique and for the same values as group 1 results.

A single correlation with regression was plotted for the combined results from groups 1 and 2 both for total against PBG and for total against free gold.

\section{Results}

CORRELATION STUDY

Good correlation was shown in group 1 patients

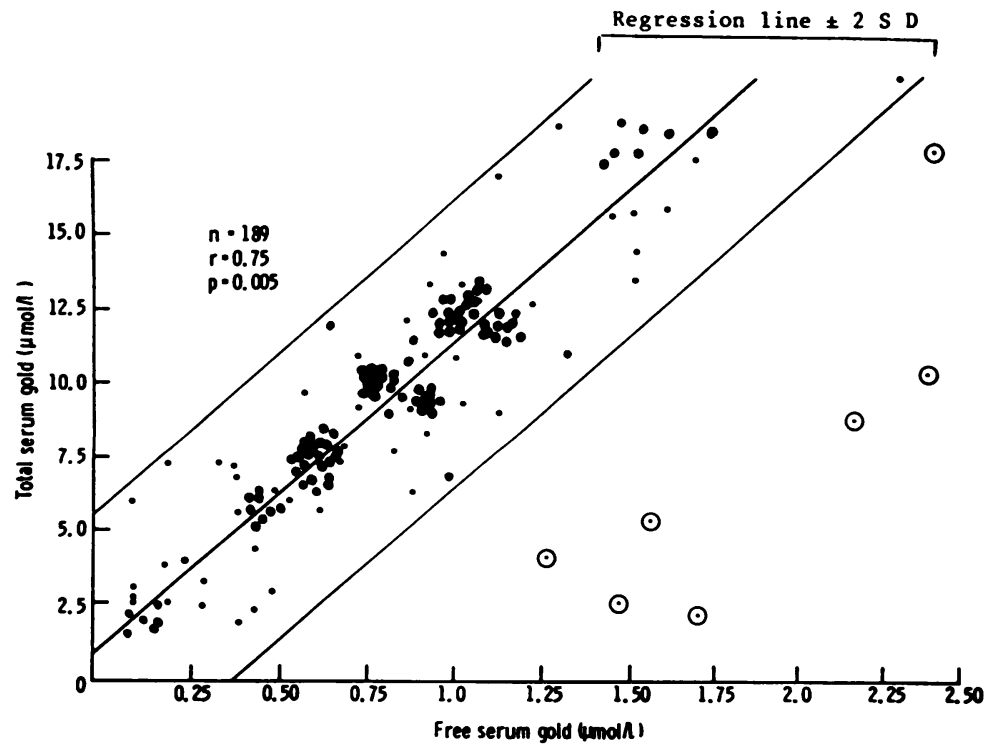

Fig. 1 Correlation between total and free serum gold including lines within $2 S D$ of the regression line. 


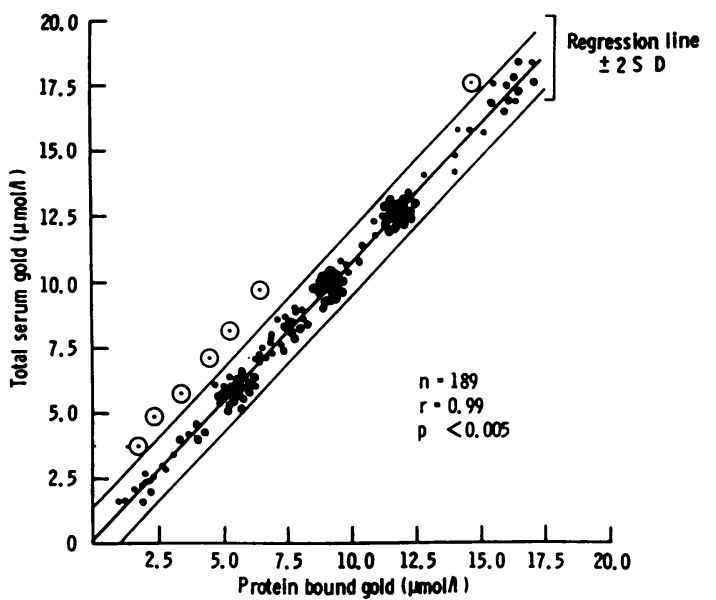

Fig. 2 Correlation between total and protein bound gold including lines within $2 S D$ of the regression line.

between total gold and free gold $(r=0 \cdot 80, p=0 \cdot 005$, $n=54$, where $p$ is the measure for the significance of the results and $n$ is the number of paired results observed) and between total gold and PBG ( $r=0.99$. $\mathrm{p}=0 \cdot 005, \mathrm{n}=54$ ).

Good correlation was also obtained in group 2 patients between total gold and free gold $(r=0 \cdot 79$, $\mathrm{p}=0.005, \mathrm{n}=135)$ and between total gold and PBG $(\mathrm{r}=0.99, \mathrm{p}=0.005, \mathrm{n}=135)$.

The single correlation with regression for results from all patients in the two study groups (i.e., the initial established group of 54 plus the nine serial analyses for the 15 patients starting therapy) again showed significant correlation both between total and free gold $(r=0.75, p=0.005, n=189)$ and between total and PBG $(r=0.99, p=0.005, n=189)$. When limits of 2SD were added to the plots of the regression lines it was observed that in each case 182 of the 189 plots were within the limits set and seven fell outside the limits (see Figs 1 and 2).

\section{Discussion}

When ultrafiltration cones were used analyses were carried out rapidly and with good precision. The results obtained from the precision study show that good reproducibility is possible for free gold in serum using this technique.

Levels of free gold were detected which were up to $12 \%$ of the total serum gold levels measured. This is in agreement with the work done by Campion $e t$ al. ${ }^{21}$ The analyses for free gold were performed up to one week after the blood samples were obtained by venous section. The results obtained differ from the studies made by Danpure, ${ }^{22}$ who was unable to detect the free gold moiety from 100 minutes onwards after gold injection.

It is evident from the results that there is goof correlation between serum total gold and free gold and between total gold and PBG for patient. starting gold therapy and for those stabilised of therapy. Furthermore, the single correlation witf regression for the combined results from the two groups of patients for total against free gold anछ total against PBG showed that in all but seven case the correlation points were within 2SD of thes regression lines (see Figs 1 and 2).

Retrospective analysis of patients notes showe that of these seven patients, five had developed rashes at the time of study and one had transient thrombocytopenia. Data on the seventh patien were not available. No other patient in either groug developed side effects over the study period. It is possible that toxicity may be related to a higher fres to total serum gold ratio and also to a lower PBG th total gold ratio.

A study is now in progress in which blood is taken from patients receiving gold therapy for RA whes present with toxic reactions and then again after the disappearance of the reaction when treatment 8 temporarily withheld. Blood is analysed for tota free, and protein bound gold and the results entere on the regression plots. In this way it may possible to show any relation existing between th toxicity of gold treatment and the distribution of gold in the serum.

Patients showing side effects in this study represe $11 \%$ of all patients studied as opposed to the more usual figure of 25 to $33 \%$. There are several possibte explanations for this low incidence of toxic reactios in the patient population studied: $(a)$ The initio group of 54 subjects was selected on the basis thant they were stabilised on therapy and might therefoße be expected to have a lower incidence of toxite reactions. ( $b$ ) The average weekly gold dose f\&r each patient in the study was $20 \mathrm{mg}$ as opposed the more usual $50 \mathrm{mg} /$ week. This regimen is used this hospital because of the apparently lower rates of toxicity. (c) The 15 patients studied in group 2 were followed up for nine weeks after starting therap禺 As the usual figure of 25 to $33 \%$ for patients showing side effects is normally applied to subjeces studied during 12 months of therapy, it is likely thot with a longer study period the incidence of toxpc reactions in the group of 15 would be greater.

The above observations show that it is possible 18 obtain reliable free gold concentrations for patien receiving gold therapy and that measurements of both free and total serum gold levels are likely to more useful parameters for monitoring patienss during chrysotherapy than total gold alone. 
addition, this might explain why previous studies have failed to relate total or PBG concentrations alone to toxic reactions. ${ }^{23}$

\section{References}

1 Danpure C J, Fyfe D A, Gumpel M J. Distribution of gold among plasma fractions in rheumatoid patients undergoing chrysotherapy compared with its distribution in plasma incubated with aurothiomalate in vitro. Ann Rheum Dis 1979; 38: 364-70.

2 Kamel H, Brown D H, Ottaway J M, Smith W E. Determination of gold in separate protein fractions of blood serum by carbon furnace atomic absorption spectrometry. Analyst 1977; 102: 645-57.

3 Ward R J, Danpure C J, Fyte D A. Determination of gold in plasma and plasma fractions by atomic absorption spectrometry and by neutron activation analysis. Clin Chim Acta 1977; 81: 87-97.

4 Francois P E, Goldberg I J L, Lawton K, Al-Ani D T, Redding H J. Distribution of gold in blood during chrysotherapy. Ann Clin Biochem 1978; 15: 324-5.

5 Van de Stadt R J, Abbo-Tilstra B. Gold binding to blood cells and serum proteins during chrysotherapy. Ann Rheum Dis 1980; 39: 31-6.

6 Pedersen S M. The binding of gold to human albumin in vitro. Intrinsic association constants at physiological conditions. Biochem Pharmacol 1981; 30: 3249-52.

7 Lorber A, Vibert G J, Harralson A F, Simon T M. Unbound serum gold: procedure for quantitation. $J$ Rheumatol $1983 ; 10$ : 563-7.

8 Smith P M, Smith E M, Gottlieb N L. Gold distribution in whole blood during chrysotherapy. J Lab Clin Med 1973; 82: 930-7.

9 Hinderling P H, Garret E R. Pharmacokinetics of the antiarrhythmic disopyramide in healthy humans. $J$ Pharmacokinet Biopharm 1976; 4: 199-230.
10 Weser J K. Sellers E M. Drug therapy-binding of drugs to serum albumin. N Engl J Med 1976; 294: 311-6.

11 Bett R J, Himmelstein K J, Patton T F et al. Pharmacokinetics of non-protein bound platinum species following administration of cis-dichlorodiammineplatinum (II). Cancer Treat Rep 1979; 63: 1515-21.

12 Pedersen M P. Binding of sodium aurothiomalate to human serum albumin in vitro at physiological conditions. Ann Rheum Dis 1986; 45: 712-7.

13 Whitlam $\mathrm{J} \mathrm{B}$, Brown $\mathrm{K} F$. Ultrafiltration in serum protein binding determinations. J Pharm Sci 1981; 70: 146-50.

14 Wijkstrom A, Westerlund D. Plasma protein binding of sulphadiazine, sulphamethoxazole and trimethoprim determined by ultrafiltration. J Pharm Biomed Anal 1983; 1: 293-9.

15 Wittfoht W, Duwe K, Kuhnz W, Nau H. Microscale ultrafiltration technique for determining free drug in $50 \mu \mathrm{l}$ serum samples. Clin Chem 1984; 30: 878-9.

16 Knott P J, Curzon G. Free trytophan in plasma and brain typtophan metabolism. Nature 1972; 239: 452-3.

17 Lee I R, Greed L C, Hahnel R. Comparative measurements of plasma binding capacity and concentration of human sex hormone binding globulin. Clin Chim Acta 1984; 137: 131-9.

18 Sophianopoulos J A, Durham S J, Sophianopoulos A J, Ragsdale $H$ L, Cropper W P. Ultrafiltration is theoretically equivalent to equilibrium dialysis but much simpler to carry out. Arch Biochem Biophys 1978; 187: 132-7.

19 Ropes M W. Diagnosis criteria for rheumatoid arthritis. Ann Rheum Dis 1959; 18: 49-53.

20 Instrumentation Laboratory Inc., Lexington, Mass, USA. Clinical applications of atomic absorption/emission spectroscopy. 1970; 72: 51-2.

21 Campion D A, Olsen R, Bohan A, Bluestone R. Interaction of gold sodium thiomalate (Myocrysin) with serum albumin. J Rheumatol 1974; 1 (suppl): 1-112.

22 Danpure C J. 'Free' plasma gold in rheumatoid patients undergoing chrysotherapy. J Physiol (Lond) 1977; 267: 25-6.

23 Gottlieb H L. Smith P M. Smith E M. Pharmacodynamics of ${ }^{197} \mathrm{Au}$ and ${ }^{195} \mathrm{Au}$ labelled aurothiomalate in blood. Arthritis Rheum 1974; 17: 171-83. 